\title{
BOEKBESPREKING
}

\section{FUSIE EN SAMENWERKING}

losbladige uitgave onder redactie van dr. J. J. Wouterse c.s., Samsom Uitgeverij, Alphen aan den Rijn 1972; band met eerste inhoud (ruim 300 bly.) $f 59,50$, aanvullingen tegen paginaprijs (thans $f 0,20$ ).

\section{door Prof. Mr. C. A. Boukema}

Om het doel van deze uitgave aan te geven zou ik het beste de inleiding kunnen overnemen, waarin de redactie uiteenzet wat met dit boek wordt beoogd. Teneinde de voor een bespreking gebruikelijke plaatsruimte niet te overschrijden voista ik met enkele citaten:

,Er is vrijwel geen onderneming die in haar toekomstplannen de mogelijkheid van samengaan met een andere onderneming geheel buiten beschouwing kan laten. Ook al meent de leiding dat fusie of een andere vorm van nauwe samenwerking binnen afzienbare tijd niet aan de orde komt, dan nog is het zaak omtrent het fusieprobleem goed georiënteerd te zijn en te blijven, want de situatie kan snel veranderen. Gezien de consolidatie van grotere en hechtere economische blokken en de daarmede verbonden vorming van steeds grotere markten bestaat voorshands geen reden aan te nemen dat het tempo waarin sinds 1960 in Nederland fusies worden voltrokken aanmerkelijk zal verflauwen. Het is daarom alleen reeds aangewezen zich in voldoende mate te verdiepen in eventuele voordelen van een fusie en in de mogelijkheid de onderneming aantrekkelijk te maken als fusiepartner. Ook is het nodig andere samenwerkingsvormen in hun consequenties te doordenken, na te gaan hoe samenwerkende concurrenten het doen, enz.". Terecht wordt opgemerkt, dat de tijd waarin het fusieproces zich a fwikkelt doorgaans vrij kort is, en dat het daarom zin heeft zich vooraf in de desbetreffende problematiek te verdiepen.

„Bij samenwerking in al haar vormen komen onvermijdelijk tal van vraagstukken aan de orde die op het terrein liggen van bepaalde specialisten; inschakeling van afzonderlijke deskundigen op het gebied van bedrijfsorganisatie, accountancy, belastingwezen, enz., blijkt dikwijls onontkoombaar; het is zeker niet de bedoeling van deze gids ook maar een van deze specialisten te vervangen. Integendeel, er wordt juist mee beoogd duidelijk te laten uitkomen hoezeer de tijdige inschakeling van deskundigen nodig is.
Maar, het is anderzijds niet zo dat de regeling van bepaalde onderdelen geheel aan hen zou moeten worden overgelaten. Het bestuur moet de transactie en haar voorbereiding in eigen hand houden en daartoe weten hoe en wanneer men van specialisten gebruik kan maken. Dit vergt dat men hun taal verstaat, beseft wat hun kracht is en weet waar hun grenzen liggen".

„De opzet is dan ook zo dat een snel overzicht van algemene perspectieven mogelijk is. Bepaalde problemen kunnen ook heel vlug met meer diepgang worden bestudeerd. De bestuurder oriënteert zich op de voornaamste punten en de algemene gang van zaken; de medewerkers gaan wat dieper in op speciale onderdelen.

De gids verschilt van een studieboek doordat er geen betoog in is opgenomen dat van begin tot eind dient te worden gevolgd, integendeel: men kan direct het onderwerp opslaan warvoor acute belangstelling bestaat (raadpleeg hiervoor de inhoudsopgaaf en het trefwoordenregister) en midden in de materie duiken. De vertakkingen van de problematiek en de consequenties van verschilleride keuzen worden in de gids door de opbouw ervan toch wel onder de aandacht gebracht". De redactie heeft getracht woordgebruik en stijl zo te houden, dat ook de niet-specialist de gedachtengang kan volgen.

"Juist de noodzaak in deze eenvoudige weergave de verschillende vakgebieden met elkaar te integreren heeft een netwerk doen ontstaan dat van vitaal belang is voor een goed verloop van het fusieproces en in deze vorm voor velen nieuw zal zijn".

Dat aan een uitgave met een dergelijke opzet behoefte bestaat lijkt mij nauwelijks voor discussie vatbaar; daarvoor behoef ik slechts te wijzen op het rapport van de Stichting Maatschappij en Onderneming (Fusies, een terreinverkenning, Den Haag, 1970), waarin op blz. 56 wordt vastgesteld, dat bij ruim de helft van de in de enquête begrepen overnamen de overgenomen partij in een dwangpositie verkeerde. Opgemerkt wordt dat men uit dit gegeven de indruk krijgt „dat vele ondernemingen in een laat, zo niet te laat stadium de bakens verzetten, i.c. tot fusie overgaan."

Of de redactie in haar, hierboven aangegeven opzet is geslaagd, kan eigenlijk het beste door de gebruiker in de praktijk worden beoordeeld. Ik beperk mij tot een aantal opmerkingen omtrent punten die mij bij het lezen opvielen; dat bij het toetsen van de bruikbaarheid van dit boek bijzondere aandacht bestond voor een be- 
paald aspect van fusie en overname (i.c. het juridische) is bij een bespreking door een vakspecialist moeilijk te vermijden.

De samenstellers gaan er terecht vanuit dat beslissingen omtrent fusie en samenwerking beslissingen zijn in het kader van de ondernemingsstrategie (1.1.). In het voetspoor van de analyse die de hoofdredacteur in zijn proefschrift heeft ontwikkeld (J. J. Wouterse, Kenmerken van fusierijpe ondernemingen, R'dam 1970) wordt daarbij de meeste aandacht gericht op de onderneming die in een impasse verkeert, voor wie gevaren dreigen voor het behoud van het vermogen of perspectieven ontstaan voor extra mogelijkheden door het opereren op grote schaal. De positie van - de op dit punt uiteraard minder problematische - grote onderneming voor wie overname van een onderneming weinig anders is dan een beslissing over de wijze waarop een voorgenomen investering wordt gedaan, komt nauwelijks ter sprake.

Aandacht wordt voorts besteed aan de partnerkeuze (hoe een of meer tot overleg bereide kandidaten kunnen worden opgespoord 1.2.), aan het organiseren van het voorbereidingsproces (2.1.), het vaststellen van de inhoud van de transactie (vorm van de fusie, waarderingsvraag. stukken 2.2.) en het effectueren van de transactie (2.3.). De op de fusie of overname volgende integratie, welke dient om de structuur tot stand te brengen die met de transactie werd beoogd zal behandeld worden in een volgende aflevering

Een aantal malen heb ik me afgevraagd of het teamwork binnen de redactie niet verbetering behoeft. Op blz. 2.1.20. wordt in verband met de taakstelling van de accountant wel melding gemaakt van de eisen welke het Fondsenreglement aan een biedingsbericht stelt, niet van de voorschriften op dit punt van de Fusiecode. Op blz. 2.1.23. komt een hoogst gebrekkige omschrijving voor van de term "geldend recht" en wordt de indruk gegeven dat het vennootschapsrecht nog ingrijpend gewijzigd moet worden terwijl deze wijzigingen al enige jaren van kracht zijn. In de gedeelten waar de betreffende kwesties worden besproken (o.m. 2.3.3. en 2.2.1.) komen deze onvolkomenheden niet voor.

Dat bij behandeling van een gecompliceerd onderwerp als het onderhavige onduidelijkheden voorkomen is welhaast onvermijdelijk. Voor een gids voor de praktijk op dit gebied kunnen echter kleine foutjes grote gevolgen hebben. Het is hier niet de plaats om detailkritiek te leveren, maar als voorbeeld van een m.i. bedenkelijke onduidelijkheid noem ik het tijd- stip, waarop de vakorganisaties moeten worden ingelicht en de gelegenheid geboden om hun oordeel te geven over de fusie of de overname. Volgens art. 18 van de Fusiecode moet dit geschieden wanneer de verwachting gewettigd is, dat overeenstemming kan worden bereikt en vóórdat definitieve overeenstemming is bereikt.

Op blz. 2.1.41. e.v. raden de samenstellers de lezers af om de fusie naar buiten bekend te maken in het stadium waarin men perspectieven ziet in een fusie of overname en dat het vroegste tijdstip, waarop bekendmaking aan de orde komt het tijdstip is, waarop wilsovereenstemming tussen de onderhandelende partijen is bereikt. Dan zou ook contact moet worden opgenomen met de vakorganisaties.

In een circulaire van 25 april 1972 is er echter door de Commissie van Fusieaangelegenheden op gewezen, dat het overleg met de vakorganisaties moet zijn voltooid vóórdat de onderhandelaren omtrent de uitgangspunten van het fusievoorstel daadwerkelijk overeenstemming bereiken. In Fusie en Samenwerking (blz. 2.3.24.) wordt weliswaar opgemerkt, dat de besturen, die tot volledige overeenstemming komen over een fusie zonder overleg met de vakorganisaties in strijd handelen met de Fusiegedragsregels van de SER, maar de redactie had hieraan m.i. dan ook de consequentie moeten verbinden om deze regels van de Fusiecode te bespreken niet in 2.3. (effectueren van de transactie), maar in 2.2. (vaststellen van de inhoud van de transactie). Een soortgelijke opmerking zou te maken zijn over blz. 2.3.13. waar gesproken wordt over bekendmaking van de fusie aan de ondernemingsraad i.p.v. over het vragen van advies zoals art. 25 van de wet op de ondernemingsraden voorschrijft.

Tenslotte een opmerking over de vormgeving van deze uitgave. De inhoudsopgave is in de huidige vorm geen geschikte gids voor de inhoud; of een bepaald probleem te vinden is onder 2.2.1. (juridische vormgeving), 2.2.2. (juridische aspecten van de keuze), 2.2.7. en 2.2.8. (juridische realisering) dan wel onder 2.3.6. (juridische verwerkelijking van fusie en overneming) kan alleen uitgemaakt worden door de betreffende onderdelen door te bladeren. Ook het systeem van nummering van bladzijden en onderdelen, dat er bijvoorbeeld toe leidt dat er behalve blz. 2.2.5. en 2.2.6. etc. ook no's 2.2.5. en 2.2.6. zijn, is weinig geslaagd. Het gebruik van de kopregel is soms (blz. 2.2.35/2.2.36) wat raadselachtig.

Enige kritiek op inhoud en vorm van deze uitgave doet overigens niets af aan mijn waardering voor de poging van de samenstellers te ko. 
men tot een gids voor de praktijk waarbij de vaak bijzonder gecompliceerde en onderling veelal samenhangende deelproblemen m.b.t. fusie en overname gefintegreerd worden behandeld in een ook voor de niet-specialist leesbare vorm. Een gids welke naar ik aanneem vooral op basis van reacties uit de praktijk nog zal worden geperfectioneerd. 